\title{
IwONA BURKaCKa
}

Uniwersytet Warszawski (Warszawa, Polska)

\section{O znaczeniu wyrazów potocznych i środowiskowych na przykładzie czasownika ogarniać i wyrazów pochodnych}

Współczesna polszczyzna cechuje się znacznym upotocznieniem i obecnością elementów języka środowiskowego, w tym młodzieżowego, które dość swobodnie przenikają do wypowiedzi oficjalnych, choć jeszcze do końca lat 80 . ubiegłego wieku można było spotkać opinie, że „wyrazy kolokwialne nie mogą awansować w „górę" bez użycia stylizacyjnego" (Lubaś 1978: 149), są przypisane do określonych wariantów stylistycznych i dopiero po zatarciu zabarwienia emocjonalnego mogą być wyzyskane w innych stylach (Smółkowa 1989: 93). Przyglądając się zawrotnej karierze takich słów, jak: przekręt, olewać, budżetów$k a$, psycholożka, urwać się w znaczeniu 'wyjść wcześniej' oraz pytaniom kierowanym do RJP dotyczącym przymiotnika zajebisty ${ }^{1}$, obserwujemy, jak szybko nacechowanie stylistyczne i ekspresywne zostaje wyparte ze świadomości Polaków - czy ostrożniej: części Polaków.

Widoczny awans polszczyzny potocznej (dotyczący jej różnych poziomów), mający wiele źródeł zewnątrz- $\mathrm{i}$ wewnątrzjęzykowych, niesie ze sobą jednak konsekwencje, których początkowo nie brano pod uwagę. Sądzono bowiem, że sięgnięcie po zasoby polszczyzny potocznej ${ }^{2}$ przywróci wiarę w słowo ${ }^{3}$ (zniszczoną lub nadwyrężona przez nowomowę) oraz odświeży język informacji i dyskusji politycznych ${ }^{4}$. Dziś zwraca się uwagę na brak precyzji czy wieloznaczność słownictwa potocznego i udział tej leksyki w różnych działaniach manipulacyjnych

1 Odpowiedź na pismo nauczyciela zaniepokojonego opinią uczniów, że przymiotnik ten nie jest wulgarny (http://www.rjp.pan.pl/index.php?option $=$ com_content\&view $=$ article\&

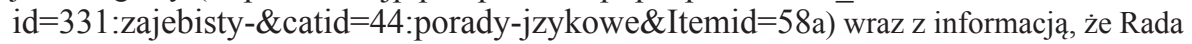
Języka Polskiego wypowiadała się już kilkakrotnie na temat nacechowania tego przymiotnika. List sygnowany numerem 114/W/2001 stanowił odpowiedź na pytanie pewnego pracownika agencji reklamowej, oburzonego tym, że klienci (pracownicy jakiejś firmy, która reklamowała swoje usługi) zakwestionowali hasło „Chcesz mieć za...sty interes - dzwoń pod numer!”

2 Do zasobów rejestru emocjonalnego - w ujęciu szkoły opolsko-lubelskiej.

Działania zapoczątkowane przez Gazete Wyborcza.

Współcześnie podobne zabiegi obserwujemy w tekstach naukowych lub popularno-naukowych. 
czy perswazyjnych. Wskazuje się także na ograniczoność słownictwa potocznego, które z trudem nadaje się do opisu procesów myślowych, abstrakcyjnych (por. np. Buttler 1977 i 1978a, b; Gajda 1999; Markowski 2005: 272-273; Lubaś 2003: 513-522, 535).

Na zmianę statusu polszczyzny potocznej wpłynęły oczywiście czynniki natury socjologicznej: nowa generacja inteligencji, migracje ludności, wpływ kultury masowej, komercjalizacja mediów (por. np. Majkowska, Satkiewicz 1999: 197-226, Gajda 1999: 12) oraz przemiany kulturowe (koncepcje postmodernistycze, liberalizacja normy językowej (por. Ożóg 2011: 57, 243-265)) i zmiana postaw użytkowników języka wobec polszczyzny potocznej, regionalnej i środowiskowej (Gajda 2000: 21). Równie ważne, a może nawet ważniejsze, są jednak właściwości jednostek potocznych, które zdecydowały o ich atrakcyjności.

Badacze, opisując słownictwo potoczne, zwracają uwagę na jego wieloznaczność, metaforyczny charakter, nacechowanie emocjonalnie, zmienność oraz odmienne mechanizmy służące jego derywowaniu ${ }^{5}$ (Buttler 1977: 91, Buttler 1979: 89, 1982; Skubalanka 1995: 68-71; Wróbel 1980: 11-13; Burkacka 2001: 192-197; 2012: 129-156).

Władysław Lubaś uważa, że „domyślna polisemia lub ścisła konkretyzacja zamierzona przez nadawcę” jest związana z przewidywaną różnorodnością znaczeniową odbioru. Stąd tak istotna w odczytaniu emocji i znaczeń jest kontekstowość (Lubaś 2003: 163), na którą zwraca również uwagę D. Zdunkiewicz-Jedynak, odnosząc się do procesów neosemantyzacji zachodzących w polszczyźnie potocznej (Zdunkiewicz-Jedynak 2008: 101), oraz K. Waszakowa, omawiając znaczenie derywatów słowotwórczych (Waszakowa 2013). A bogata metaforyzacja łącznie z mutylacją, „ekwilibrystyką słowotwórczą” i derywacją ujemną są elementami gier słownych, budujących nastrój zabawy i służących ekspresywnej autoprezentacji członków jej grupy. Zdaniem Lubasia zmuszają one uczestników dyskursu do przyjęcia podobnego podejścia (pozy - w ujęciu Lubasia) (Lubaś 2003: 162). W niektórych opisach zwraca się również uwagę na to, że elementy potoczne pełnią też funkcję fatyczną (Pisarek 2000: 16).

Owej wskazywanej przez badaczy wieloznaczności, zwanej niekiedy „wielkim luzem semantycznym" (Lubaś 2003: 176), rozwiniętą homonimicznością (Buttler 1982: 64) czy wielofunkcyjnością, towarzyszy płynność kategorii części mowy $^{6}$ (Lubaś 2003: 175), niekiedy unieruchamianie fleksji, usamodzielnienie członów niegdyś związanych ${ }^{7}$, czasami duża wariantywność fonetyczna czy wy-

Na przykład: dezintegracja, derywacja ujemna, wyspecjalizowane sufiksy. Na odrębne środki słowotwórcze służące pomnażaniu leksyki potocznej, w tym ekspresywnej, wskazywali także inni badacze (por. Satkiewicz 1978, Grabias 1974, 1978, Lubaś 2003: 175-176, Burkacka 2001: 192-197, 2012: 129-146).

${ }^{6} \quad$ Na przykład wyrazy super, ekstra, mega pełnią funkcję przymiotników i przysłówków. Wspomniane wyżej wyrazy super, ekstra, mega, a także wege, eko i wiele innych. Niektóre $\mathrm{z}$ nich stały się nawet podstawą derywatów, np. supernowy, superaśny, supernowo. 
stępowanie w tekstach o składni eliptycznej, co prowadzi do wielości możliwych uzupełnień niesprzyjających precyzji znaczeniowej.

D. Buttler zwraca uwagę, że jednostki potoczne, a zwłaszcza kolokwializmy czasownikowe, są wielofunkcyjne - „można mówić o zjawisku rozwiniętej homonimiczności wyrazów potocznych (np. gazować 'szybko biec' i 'pić alkohol')" (Buttler 1982: 64). Źródłem nacechowania tych jednostek jest urzeczowienie (np. tankować) czy substantywizacja człowieka (np. wsiaknać), także uzwierzęcenie (np. wyniuchać).

Czy rzeczywiście mamy do czynienia z wielkim luzem semantycznym, polisemią (wieloznacznością), wielką metaforycznością, rozmyciem semantycznym tych jednostek czy raczej z konkretyzacją znaczenia, dokonywaną w danej sytuacji komunikacyjnej, której uczestnicy znają zasady doboru elementów, a właściwe odczytanie informacji wymaga znajomości kontekstu, w tym właściwego odczytania emocji. Przyjrzyjmy się przykładom: czasownikom ogarnąć, ogarniać i ich derywatom, występującym w komunikacji nieformalnej, mówionej, tekstach potocznych i środowiskowych (młodzieżowych) ${ }^{8}$.

Czasownikom ogarnać i ogarniać przypisuje się w słownikach wiele znaczeń: według Stownika języka polskiego pod redakcją Witolda Doroszewskiego (dalej: SJP Dor.) - dziewięć znaczeń (w tym jedno potoczne, jedno rzadkie i jedno przestarzałe); Stownika języka polskiego pod red. Mieczysława Szymczaka (dalej: SJP Sz) - siedem znaczeń ${ }^{9}$ z których jedno opatrzone jest kwalifikatorem potoczne; Praktyczny stownik wspótczesnej polszczyzny pod red. H. Zgółkowej ${ }^{10}$ (dalej: PSWS) - osiem ${ }^{11}$. Uniwersalny słownik języka polskiego pod redakcją Stanisława Dubisza (dalej: USJP) grupuje sześć znaczeń w jedno i opatruje je kwalifikatorem książkowe (w SJP Dor. znaczenia są notowane bez kwalifikatora) oraz jedno potoczne. Znaczenie 1a w USJP zachowuje związek ze znaczeniem podstawy słowotwórczej czasownikiem garnać książk. a) 'przysuwać do siebie'12. Inne znaczenia mają charakter metaforyczny, por:

$8 \quad$ Dlaczego wybrałam te czasowniki, a nie inne wyrazy? Kilka miesięcy temu poproszono mnie o komentarz dotyczący niepoprawności czy nadużywania czasownika ogarnąć we współczesnych wypowiedziach. Pomyślałam wtedy, że znam wiele innych wyrazów, które bardziej zasługują na omówienie niż ogarnąć. Po pewnym czasie jednak przyjrzałam się dokładniej użyciom tego czasownika i dostrzegłam, w jak wielu kontekstach bywa stosowany i co się z tym wiąże - jak wiele znaczeń czy odcieni znaczeniowych wyraża (zwykle wyrazom modnym towarzyszy rozmycie semantyczne, brak precyzji) (por. np. Markowski 2005: 189-191, 205-206, 211).

$9 \quad$ SJP Sz., Warszawa 1979, t. 2. s. 489.

$10 \quad$ Praktyczny stownik współczesnej polszczyzny pod red. H. Zgółkowej, t. 26, s. 96-97, Poznań 2000.

11 Znaczenie 8 jest opatrzone kwalifikatorem dawne 'zagarnąć, uzyskać, zawładnąć' (PSWP: s. 96-97).

12 Znaczenie b wg USJP p ma charakter przenośny 'przyciągać, gromadzić, zjednywać, przygarniać, brać pod opiekę'. 
USJP: 1. książk. a) 'ująć (ujmować) w ramiona, objąć (obejmować)', b) 'otoczyć (otaczać) ze wszystkich stron', c) 'rozprzestrzenić (rozprzestrzeniać) się’, d) ‘o uczuciach, wrażeniach, stanach: przeniknąć (przenikać)’, e) 'pojąć (pojmować), zrozumieć (rozumieć)’, 2. pot. (znaczenie podane i omówione w dalszej części tekstu).

Znaczenia te motywują zaledwie kilka derywatów: nieogarniony, nieogarnięty, ogarnienie 2. 'metonimia', wszechogarniajacy (por. Słownik gniazd słowotwórczych współczesnego języka ogólnopolskiego, t. III: 211, 547-548; dalej SGS). Brak wśród nich tak popularnego wśród młodzieży derywatu nieogar, co jednak nie powinno dziwić, ponieważ SGS liczy już 10 lat (licząc od daty wydania) i zawiera przede wszystkim leksykę ogólną (a także terminy i inne jednostki zamieszczone w słownikach źródłowych - z pewnymi wyjątkami ${ }^{13}$ ). Przegląd zasobów Narodowego Korpusu Języka Polskiego (dalej: NKJP) też nie przynosi nowych znalezisk słowotwórczych (derywatów).

Przyjrzyjmy się potocznemu znaczeniu czasowników ogarniać, ogarnąć:

SJP Dor.: a) 'zaopatrzyć kogo w odzież, ubranie; ubrać, odziać, okryć schludnie', b) 'doprowadzić do porządku, uporządkować, uprzątnąć; oczyścić, omieść; przygładzić'; SJP Sz.: częściej dk. 'doprowadzić coś do względnego porządku, sprzątnąć z grubsza, niedokładnie" ${ }^{14}$;

USJP: pot. 'niezbyt dokładnie posprzątać, oczyścić, uporządkować';

Praktyczny słownik współczesnej polszczyzny pod red. H. Zgółkowej (dalej: PSWP): 'doprowadzić coś do ładu, jako tako posprzątać' bliskoznaczne: uprzątać, posprzątać, sprzątać, doprowadzić do ładu.

Lepszą definicję znaczenia - bo bliższą współczesnemu rozumieniu - notują SJP Sz., USJP i PSWP. W świetle definicji tam zamieszczonych oraz naszej intuicji językowej dobre jest zdanie: Ogarnęłam pokój, posprzątam go jutro. Choć w podanym (w SJP Dor.) synonimie: przygładzić wskazuje się pośrednio na niedokładność, niepełność.

Element znaczenia odnoszący się do powierzchowności działań, niedokładności znajduje odzwierciedlenie we frazeologizmie (notowanym w USJP) ogarnąć coś (np. pokój, mieszkanie) po wierzchu, z wierzchu, por. przykłady:

1. Zachowuje się jak facet $\mathrm{z}$ amerykańskich dowcipów rysunkowych, uwalony na kanapie, przed telewizorem, z puszką piwa w ręku. Dobrze, że chociaż obiady gotuje i trochę ogarnie w domu. Bo tak to bym jeszcze się musiał po różnych stołówkach żywić (M. Cieślik, 2004, Śmieszni kochankowie, cyt. za: www.nkjp.pl, dostęp: 24.04.2014);

13 Zamieszczano nowe jednostki, znane redaktorom słownika (uzupełnienia redakcyjne), zrezygnowano zaś z regionalizmów i archaizmów (szczegółowe zasady ekscerpcji zostały podane we wstępach do I i III tomu SGS).

14 Warszawa 1979, t. 2, s. 489. 
2. Ej, ogarnij jakoś ten burdel. (słownik slangu miejskiego, http://www.miejski.pl; dostęp 16.01.2014).

Czasownik dokonany jest też składnikiem ekspresywnych zwrotów o znaczeniu 'uspokój się, zrób porządek ze sobą, ze swoim zachowaniem' (znaczeniem zbliża się do nowych znaczeń czasownika ogarnąć się), np.

1. Ogarnać butę: [Ktoś chlapie cię wodą na basenie] Ogarnij bułe, szmato !!! (słownik slangu miejskiego, http://www.miejski.pl; dostęp 16.01.2014) ${ }^{15}$.

2. Ogarnać downa: -aleee bedzie fajnie, ja pierdole ale bedzie zajebiście :D!!! . . -ogarnij downa, wiem (słownik slangu miejskiego, http://www.miejski.pl; dostęp 16.01.2014).

3. Ogarnać fazę lub faziurę: 1. - Aj znowu mnie zabili. - No ogarnij faziurę ziomek (słownik slangu miejskiego, http://www.miejski.pl; dostęp 16.01.2014); 2. - Badaj, gość uniknął stłuczki w ostatnim momencie. - Noo, ogarnął faziurę ładnie (słownik slangu miejskiego, http://www.miejski.pl; dostęp 16.01.2014).

Niekiedy istotne jest skupienie się na czymś, poważne (poważniejsze) podejście do zagadnienia (por. ostatni z przywołanych przykładów użycia).

Znaczenie czasownika ogarnać w wypowiedziach środowiskowych zbliża się niekiedy do znaczenia 1e w USJP 'pojąć, pojmować, poznać, poznawać'. Jednak zwykle nie chodzi o dogłębne zrozumienie istoty sprawy, problemu czy zjawiska, tylko o nauczenie się czegoś, przyswojenie, por:

1. Ogarnąłeś Analizę na kolosa ? - Nie dam rady, kto to wymyślił, to jest mega trudne (słownik slangu miejskiego, http://www.miejski.pl; dostęp 16.01.2014);

2. Ogarnij te matme, bo kolejny rok przekiblujesz w tej klasie. (słownik slangu miejskiego, http://www.miejski.pl; dostęp 16.01.2014).

Ogarnąc może jednak nieść inne znaczenia: 'załatwić coś, zdobyć coś (często coś nielegalne), por.

1. Eee Marek ogarnąłeś tego gieta na jutro na impreze? - Taa... jasne (słownik slangu miejskiego, http://www.miejski.pl; dostęp 16.01.2014);

2. - Wpadniesz do mnie? - Nie mogę. Ogarniam buchy dla kumpla. (słownik slangu miejskiego, http://www.miejski.pl; dostęp 16.01.2014);

lub 'zauważyć, zaobserwować coś (interesującego czy niezwykłego dla nadawcy, a pewnie i odbiorcy wypowiedzi)':

Ogarnij akcję, wczoraj do Rudego psy się wsypały na chatę! - Ogarnij, w tym tygodniu 3 sprawdziany :/ (słownik slangu miejskiego, http://www.miejski.pl; dostęp 16.01.2014).

15 Wszystkie cytaty podaję w oryginalnej pisowni. 
Czasowniki ogarnąć, ogarniać się są odnotowane w kilku słownikach z dość podobnymi definicjami znaczenia:

SJP Dor:: rzad. ogarniać się 'doprowadzić do porządku swój wygląd, strój; ubrać się jako tako; zaopatrzyć się w ubranie';

SJP Sz.: rzad. ogarniać się 'doprowadzić do porządku swój strój, wygląd';

USJP: 'doprowadzić (doprowadzać) swój strój, wygląd do porządku’ ;

PSWP: 'doprowadzić swój wygląd do porządku' (bliskoznaczne: ubrać się, przywdziać, narzucić (wrzucić) coś na grzbiet (na siebie), wdziać, włożyć; poprawić fryzurę, przyczesać się; pozapinać guziki' antonimy: rozebrać się, porozpinać guziki.

W odmianie młodzieżowej czy odmianach - jeśli przyjmujemy, że istnienie wielość tych odmian (gwar młodzieżowych) - znaczenie to zostało nieco zmodyfikowane, co wiąże się z rozszerzeniem łączliwości leksykalnej tej jednostki. Nie tylko doprowadzamy do porządku swój strój i wygląd, por.:

1. Ogarnij się, zaraz wychodzimy. Zmień może spodnie, te się nie nadają. (zasłyszane) 2. Stary ogarnij się, bo wyglądasz jak cipa! (słownik slangu miejskiego, http://www. miejski.pl; dostęp 16.01.2014);

3. Mega śmierdzisz weź się ogarnij (słownik slangu miejskiego, http://www.miejski. pl; dostęp 16.01.2014),

ale także swój stan umysłu, zachowanie (często czasownik występuje w rozkaźniku), por. Ogarnij się, dziewczyno, ile można płakać po facecie (zasłyszane).

2. Ale się sfazowałem zaraz was pozabijam! Ogarnij się jesteś pijany (albo naćpany) (słownik slangu miejskiego, http://www.miejski.pl; dostęp 16.01.2014).

3. - ale on jest boski. - ogarnij się, okropny jest! (słownik slangu miejskiego, http:// www.miejski.pl; dostęp 16.01.2014);

4. - Ale ty masz brzydkie spodnie gdzie ty je kupiłaś? - Ogarnij się, spójrz na siebie.... Wcale nie masz ładniejszych rzeczy... (słownik slangu miejskiego, http://www. miejski.pl; dostęp 16.01.2014);

5. - stary przestań pierdolić! ogarnij się wreszcie! (słownik slangu miejskiego, http:// www.miejski.pl; dostęp 16.01.2014);

6. Nie wiem jak to zrobić. Jestem bezradny. - Weź sie OGARnij (słownik slangu miejskiego, http://www.miejski.pl; dostęp 16.01.2014).

Ten wspominany powrót do porządku przybiera więc różne formy: dotyczy świata zewnętrznego - wyglądu osób, a także wewnętrznego, który przejawia się w zachowaniu człowieka. W nasz sposób myślenia wpisane jest przeświadczenie, że pożądany jest stan typowości, zachowania stabilnego pod względem emocjonalnym, bez widocznego działania używek (alkoholu, narkotyków), akceptowanego w danym środowisku. Umiejętność odnalezienia się, rozumienia sytuacji, załatwienia czegoś, czasami cwaniactwa, zwykle była opisywana za pośrednictwem słownictwa potocznego i pomimo zmian pokoleniowych nadal jest brana pod uwagę w ocenie człowieka. Stąd pojawiają się derywaty z partykułą nie - 
nieogar, nieogarek, nieorganizator, które najczęściej oznaczają osobę, która nie rozumie czegoś, nie orientuje się w czymś, nie zachowuje w odpowiedni sposób lub zachowuje się niezdarnie, niewłaściwie ${ }^{16}$, por. przykłady:

1. Ale ten Adrian to nieogar padł na cycku i niepotrafi się przyznać - Ta kompletny lamus... (słownik slangu miejskiego, http://www.miejski.pl; dostęp 16.01.2014).

2. - Zobacz jak ona się ubrała! - Nieogar!! (słownik slangu miejskiego, http://www. miejski.pl; dostęp 16.01.2014).

3. Ach, ostatnio starałem się przejść tą kampanię. - No, ciężka, co? Ci Swordsmani mogliby się iść topić! - Ale o co chodzi? - Won stąd, nieogarku! (słownik slangu miejskiego, http://www.miejski.pl; dostęp 16.01.2014).

Nieogarem można nazwać również stan, gdy się czegoś nie rozumie, ma się kłopoty z koncentracją lub jest się w stanie po zażyciu środków odurzających, por:

1. Stary, ale wczoraj dowaliłem. Nieogar jak ch**. (słownik slangu miejskiego, http://www.miejski.pl; dostęp 16.01.2014).

2. Zobacz jaki naćpany, jaki nieogar ma na papie (słownik slangu miejskiego, http:// www.miejski.pl; dostęp 16.01.2014).

3. Ale masz nieogarniatora (słownik slangu miejskiego, http://www.miejski.pl; dostęp 16.01.2014).

4. Dzisiaj egzamin? - nieogarniator (słownik slangu miejskiego, http://www.miejski. pl; dostęp 16.01.2014).

Tu na marginesie warto dodać, że ów porządek i związana z nią kompletność, typowość przywoływane są w leksyce potocznej i środowiskowej na różne sposoby, np. we frazeologii młodzieżowej (gimnazjalnej): wszystkie kredki w pudełeczku? 'dobrze się czujesz?', wszyscy w domu? 'dobrze się czujesz?', mieć pogięte blachy 'zachowywać się dziwnie', mieć zabawki na wysokich pótkach 'mieć nierówno pod sufitem' ${ }^{17}$.

Rzeczownik ogarniętość, pochodny od formy ogarnięty, oznacza zaś umiejętność odnalezienia się w sytuacji, rozeznanie w czymś, stosowność zachowania, por.

Co ma dla Ciebie największe znaczenie - pieniądze, wygląd czy inteligencja? Ogarniętość mój drogi, ogarniętość (http://ask.fm/Rodeel/best, dostęp: 8.05.2014);

Szukasz osób do wspólnej gry? (...) jak ktoś chętny zapraszam do kontaktu (...) Wiek 21+ albo ogarnietość jako taka... (http://www.pathofexile.pl/forum/viewtopic. php?f=7\&t=1697\&start=70, dostęp: 8.05.2014);

$\overline{16}$ Niekiedy znaczenie rzeczownika nieogar zbliża się do znaczenia przymiotnika nierozgarnięty 'pozbawiony bystrości umysłu, nieinteligentny' (książk., USJP).

17 Przywołane związku frazeologiczne zostały odnotowane przez p. Katarzynę Gańko w jej pracy magisterskiej, która powstała pod moim kierunkiem w r. ak. 2012/2013. 
Nowy klub FORFUN szuka zawodników. Wymagania: 15+ lat, ogarniętość, mikrofon+słuchawki, Team sapek, odnalezienie się w grze zespołowej (http://www.fifaplay.com.pl/topic/86815-nowy-klub, dostęp: 8.05.2014).

Spoglądając na przywołane tu próby podania znaczeń czy kontekstów, w których mogą wystąpić czasowniki ogarniać, ogarnać, a zwłaszcza ich zaprzeczone formy, należy podkreślić, że wielość niesionych sensów zbliża je do czasownikowych wulgaryzmów, które cechuje mnogość znaczeń czy funkcji. Różni - niemożność utworzenia czasowników prefiksalnych ${ }^{18}$, ponieważ w formach ogarniać, ogarnąć występuje już przedrostek (a istnieją ograniczenia w liczbie przyłączanych prefiksów do podstaw czasownikowych).

Kontekstowość znaczeń jest istotną cechą jednostek potocznych czy środowiskowych i wynika po pierwsze - z atrakcyjności niektórych mechanizmów pomnażania leksyki (zwłaszcza procesów neosemnatyzacji), a po drugie - z przyjętej przez młode i średnie pokolenia postawy wobec życia i języka: lepiej mówić nie na poważnie, nie na serio, z ironią, dystansem do opisywanych zdarzeń i stanów, a czynności - głownie te nielubiane, nieinteresujące - wykonywać pobieżnie, powierzchownie. Ważna jest orientacja, znajomość konwencji, a nie - gruntowna wiedza. Stąd kariera czasownika ogarnacć i jego derywatów: świetnie wyrażają takie podejście do życia. A w opisie jednostek potocznych dobrze sprawdza się podejście kognitywne, a zwłaszcza teoria amalgamatów (integracji pojęć, por. Fauconnier, Turner 2002, Grzegorczykowa 2010: 97-104, Libura 2007), w której podkreśla się, że znaczenie jest tworzone w użyciu, jest potencją, i w jego odczytaniu ważna jest wiedza kulturowa rozmówców, dzięki której dokonuje się aktualizacja sensu. Element znaczenia 'robić porządek, przywracać ład' jest wspólny przywołanym kontekstom (jest inwariantem) i niesie ze strony nadawcy pozytywne nacechowanie. Ów porządek czy ład może odnosić się do porządku w mieszkaniu, w ubiorze, zachowaniu, w życiu człowieka (opanowanie emocji, wykonywanie typowych zajęć, prac), jeśli zaś na porządku dziennym jest korzystanie z używek, to oznacza ich kupno (zapewnienie ich obecności). Aby właściwie zrozumieć informację, należy wiedzieć, jak wygląda ów porządek.

\section{Bibliografia}

Burkacka I. (2001), Porównawcza analiza gniazdowa wybranych leksemów neutralnych i nacechowanych ekspresywnie, Warszawa.

Burkacka I. (2012), Kombinatoryka sufiksalna w polskiej derywacji odrzeczownikowej, Warszawa. Buttler D. (1977), Neologizmy potoczne powojennej polszczyzny, „Przegląd Humanistyczny” XII, s. 99-105.

Buttler D. (1978a), Polskie słownictwo potoczne. IV. Frazeologia, „Poradnik Językowy”, z. 1, s. $5-19$.

18 Poza strukturą z przedrostkiem $n a-$. 
Buttler D. (1978b), Struktura polskiego stownictwa potocznego, [w:] Studia nad sktadnia polszczyzny mówionej, red. T. Skubalanka, Lublin, s. 111-118.

Buttler D. (1979), Powojenne ekspresywizmy polskie, „Prace Filologiczne”, t. XXIX, s. 85-90.

Buttler D. (1982), Czasowniki potoczne współczesnej polszczyzny, „Socjolingwistyka” 4, s. 55-66.

Fauconnier G., Turner M. (2002), The Way We Think. Conceptual Blending and the Mind's Hidden Complexities, New York.

Gajda S. (1999), Współczesna polska rzeczywistość językowa i jej badanie, [w:] Mowa rozświetlona myśla, red. J. Miodek, Wrocław, s. 8-14.

Gajda S. (2000), Media - stylowy tygiel współczesnej polszczyzny, [w:] Język w mediach masowych, red. J. Bralczyk, K. Mosiołek-Kłosińska, Warszawa, s. 19-27.

Grabias S. (1974), Formacje ekspresywne typu koszul, spodzień, „Prace Filologiczne” t. XXV, s. $42-43$.

Grabias S. (1978), Derywacja a ekspresja, [w:] Studia nad składnia polszczyzny mówionej, red. S. Grabias, J. Mazur, K. Pisarkowa, Wrocław, s. 89-102.

Grzegorczykowa R. (2010), Wprowadzenie do semantyki językoznawczej, Warszawa.

Internetowy słownik slangu młodzieżowego: www.miejski.pl (dostęp: 16.01.2014).

Libura A. (2007), Amalgamaty kognitywne. Powstanie i rozwój koncepcji integracji pojęciowej, [w:] Amalgamaty kognitywne w sztuce, red. A. Libura, Kraków, s. 11-66.

Lubaś W. (1978), Stownictwo kolokwialne i niekolokwialne. Próba definicji, [w:] Z zagadnień współczesnego języka polskiego, Prace Językoznawcze 91, Wrocław, s. 144-149.

Lubaś W. (2003), Polskie gadanie. Podstawowe cechy i funkcje potocznej odmiany polszczyzny, Opole.

Majkowska G., Satkiewicz H. (1999), Język w mediach, [w:] Polszczyzna 2000, red. W. Pisarek, Kraków, s. 181-196.

Markowski A. (2005), Kultura języka polskiego. Teoria. Zagadnienia leksykalne, Warszawa. NKJP: Narodowy Korpus Języka Polskiego, www.nkjp.pl (dostęp: 24.04.2014).

Ożóg K. (2011), Polszczyzna przełomu XX i XX wieku. Wybrane zagadnienia, Rzeszów.

Pisarek W. (2000), Język w mediach, media $w$ języku, [w:] Język w mediach masowych, red. red. J. Bralczyk, K. Mosiołek-Kłosińska, Warszawa, s. 9-18.

PSWP: Praktyczny słownik współczesnej polszczyzny, red. H. Zgółkowa, Poznań 1994-2005.

SGS: Stownik gniazd stowotwórczych wspótczesnego języka ogólnopolskiego, t. 1 i 2 red. H. Jadacka, Kraków 2001, t. III i IV, red. M. Skarżyński, Kraków 2004.

SJP Dor.: Słownik języka polskiego, red. Witold Doroszewski, Warszawa (wyd. elektroniczne CD 1997).

SJP Sz.: Stownik języka polskiego, red. M. Szymczak, Warszawa 1978.

Satkiewicz H. (1978), Wskaźniki stowotwórcze przynależności wyrazów do stylu potocznego, [w:] Z zagadnień słownictwa wspótczesnego języka polskiego, Prace Językoznawcze 91, Wrocław, s. $161-167$.

Skubalanka T. (1995), O stylu poetyckim i innych stylach języka. Studia i szkice teoretyczne, Lublin. Smółkowa T. (1989), Nominacja językowa na materiale nazw rzeczownikowych, Wrocław.

USJP: Uniwersalny stownik języka polskiego, red. S. Dubisz, Warszawa 2003.

Waszakowa K. (2013), Studniówka Tuska. O kontekstowym odczytywaniu znaczeń derywatów stowotwórczych, [w:] Mówię, więc jestem. Rozmowy o współczesnej polszczyźnie 4, red. M. Milewska-Stawiany, E. Rogowska-Cybulska, Wydawnictwo Uniwersytetu Gdańskiego, Gdańsk, s. $127-137$.

Wróbel H. (1980), Uwagi teoretyczno-metodologiczne o badaniu odmian współczesnej polszczyzny, [w:] Wspótczesna polszczyzna i jej odmiany, red. H. Wróbel, Katowice.

Zdunkiewicz-Jedynak D. (2008), Wyktady ze stylistyki, Warszawa. 


\title{
Iwona Burkacka
}

\section{On the meaning of colloquial and environmental words on the basis of the verb ogarniać and its derivatives}

\begin{abstract}
Summary
The article presents the colloquial and environmental meanings of the verbs ogarniać, ogarnać się, ogarniać się and their derivatives: nieogar, nieogarek, nieogarniator in the context of the deliberations on semantic features of colloquial lexemes (among other things its developed polysemy, semantic blur, figurativeness, contextualization of meanings).

In the meaning of the verb ogarnać and its derivatives one can observe a connection with the attitude of young people. We can observe their approach to life and language, their detachment from the described events, a stereotypicality of emotions and assessments, the superficiality of cognition, irony. The joint element of the meaning 'to put (sth) in order', 'to restore order' can refer to both objects (tidiness in the house, neatness of clothing) and a person (their appearance, behaviour, the performed actions and the emotions they express). The aforementioned order is connected with the typicality of behaviours and experiences, and if the use of stimulants is within the limits of that typicality, then that means their purchase. In order to understand the meaning of the verbs ogarnać, ogarniać and their derivatives it is necessary to understand their cultural context; one should know what the world order looks like.
\end{abstract}

